후천성 혈우병 $\mathrm{A}$

김진석

연세대학교 의과대학 내과학교실 혈액내과

\title{
Acquired Hemophilia A
}

Jin Seok Kim

Division of Hematology, Department of Internal Medicine, Yonsei University College of Medicine, Seoul, Korea

Received: 14 December 2017 Revised: 1 August 2019 Accepted: 5 August 2019

*Corresponding author: Jin Seok Kim, MD, PhD

Division of Hematology, Department of Internal Medicine, Yonsei University College of Medicine, Severance Hospital, 50-1 Yonsei-ro, Seodaemungu, Seoul 03722, Korea Tel: +82-2-2228-1972

Fax: +82-2-393-6884

E-mail: hemakim@yuhs.ac
Copyright (C) Korean Society on Thrombosis and Hemostasis. All rights reserved.
Acquired hemophilia $\mathrm{A}$ is rare but fatal bleeding disorder caused by an autoantibody against factor VIII. Acquired hemophilia $A$ is more prevalent in the elderly patients and associated with other underlying diseases such as autoimmune disorders, malignancies, pregnancy, infection and several drugs. The bleeding pattern of acquired hemophilia $A$ is quite different from that of congenital hemophilia $A$. Thus, acquired hemophilia A should be suspected in the presence of bleeding with sudden onset, often severe, which occurs spontaneously or after minor trauma, following invasive procedures or surgical interventions in patients without a personal or family history of bleeding. The main goal of the treatment for acquired hemophilia $A$ should be the control of bleeding with the use of bypassing agents and the eradication of autoantibodies with the use of immunosuppressive agents. Because the remained level of factor VIII is not correlated with the risk of fatal bleeding, appropriate hemostatic management should be applied in patients with clinically significant bleeding regardless of the level of factor 8 or the inhibitor level of factor VIII. Because current recommendations for acquired hemophilia A are developed mainly based on the retrospectively available data, larger multicenter prospective trials should be conducted for developing appropriate treatments.

\section{Keywords: Acquired hemophilia A, Bleeding, Bypassing agents, Immunosuppressive agents}

\section{서론}

후천성혈우병 $\mathrm{A}$ 는 8 번 응고인자에 대한 자가면역항체가 발생하여 혈중 8 번 응고인자가 억제되고 고갈되어 출혈과 관련된 합병증이 발생하는 매우 드문 질환이다. ${ }^{1,2}$ 종종 생명을 위협하는 치명적인 출혈 합병증이 발생하는 것으로 알려져 있어, 관련된 증상이 동반된 환자에서 의심을 하여 조기에 진단을 하는 것이 매우 중요하다.

후천성혈우병 $\mathrm{A}$ 는 100 만 명 중 1년에 0.2-1.48명이 발생하는 것으로 보 고되고 있다. 20-30대 여성에서는 임신이나 자가면역성 질환과 관련하여 종종 발생하나, 대부분은 65세 이상의 고령(중앙값 64-78세)에서 남녀에 모두 비슷한 비율로 발생한다. ${ }^{1-4}$ 소아에서는 매우 드문 것으로 알려져 있 다. 자가면역성 질환(전신홍반루푸스, 류마티스관절염 등), 악성종양, 임신 (대부분 첫 번째 임신에서 발생하며, 출산 후 1-4개월에 발생함. 자가항체 가 태반을 통과하므로 태아에 출혈 위험이 있음), ${ }^{5,6}$ 감염, ${ }^{7}$ 약제 등 후천성 혈우병 A 발생에 관련된 원인이 있는 경우가 $50 \%$ 정도 되며, 나머지 $50 \%$ 에서는 원인불명(idiopathic)으로 밝혀진 관련된 질환 없이 발생하는 것으 로 알려져 있다. ${ }^{1,8}$ 비록 약 $30 \%$ 정도에서는 출혈이 심하지 않아 출혈에 대 한 지혈치료가 필요 없으나, 최근의 대규모 보고에 따르면 $94.6 \%$ 에서는 출 혈성 임상양상이 동반되었고, $77 \%$ 의 자연출혈과 $70 \%$ 의 심각한 출혈(혈 색소 $<8 \mathrm{~g} / \mathrm{dL}$ 또는 혈색소 $>2 \mathrm{~g} / \mathrm{dL}$ 감소로 정의됨)이 관찰되었다. ${ }^{3}$ 선천성 혈우병과는 나타나는 임상양상에 차이가 있다. 선천성혈우병에서 주로 관 찰되는 관절강내출혈(hemarthrosis)은 드물고, 후천성혈우병 A에서는 피
하출혈이 흔하게 관찰된다(> $80 \%)$. 근육내 출혈이나 위장관계 출혈도 종 종 관찰된다(Table 1). ${ }^{1,2,4}$ 사망률은 특히 65 세 이상의 고령이나 기저 악성 종양을 동반한 경우에는 $20 \%$ 이상으로 보고되고 있다. ${ }^{2}$ 기저질환 관련 사 망이 많고, 출혈에 의한 사망은 5-10\% 정도로 알려져 있다(이전 연구에서 $3.2 \%$ 와 ${ }^{3} 9.1 \%$ 로 ${ }^{4}$ 보고됨). 후천성혈우병 $\mathrm{A}$ 는 진단의 지연으로 인하여 치명 적인 출혈에 의한 사망이 발생할 수 있으며, 진단과 적절한 초기 조치가 되 지 않은 상태에서 출혈 조절을 위한 추가 시술 중에 출혈 합병증이 더 악 화될 수 있으므로, 적절한 진단과 치료에 대한 교육이 매우 중요한 질환이 라 할 수 있다.

\section{진단}

과거에 출혈 경향이 없었고, 출혈 질환에 대한 가족력이 없는 환자에서 갑 자기 발생하거나 가벼운 시술이나 상처 후에 심한 출혈이 발생하는 경우 에는 후천성혈우병 $\mathrm{A}$ 를 반드시 의심해 보아야 한다. 진단을 하는 데 초기 에 가장 중요한 검사 소견은 프로트롬빈시간(prothrombin time)은 정상 이고, 활성화부분트롬보플라스틴시간(activated partial thromboplastin time, aPTT)이 연장이 있으면서, 혼합검사(mixing test, 정상인의 혈장과 같은 양의 환자의 혈장을 넣어서 환자의 연장된 $\mathrm{aPTT}$ 의 교정 정도를 확인 하는 검사)에서 환자의 연장된 $\mathrm{aPTT}$ 가 $50 \%$ 이상 교정이 되지 않는 결과 이다. ${ }^{9}$ 응고인자 8 번의 불활성화는 시간과 온도에 의존적이기 때문에 후천 성혈우병 A 진단을 위한 혼합검사 판독에 있어 상온에서 즉시 검사 결과 
Table 1. Comparison of acquired hemophilia A \& congenital hemophilia $A$

\begin{tabular}{|c|c|c|}
\hline & Acquired hemophilia A & Congenital hemophilia A \\
\hline Age & Commonly in elderly & $\begin{array}{l}\text { More commonly in young chil- } \\
\text { dren }\end{array}$ \\
\hline Sex & Both male and female & Most in male \\
\hline $\begin{array}{l}\text { Kinetics of anti- } \\
\text { body }\end{array}$ & $\begin{array}{l}\text { Type } 2 \text { kinetics. } \\
\text { Lack of correlation be- } \\
\text { tween inhibitor level and } \\
\text { residual factor } 8 \text { level }\end{array}$ & Type 1 kinetics. \\
\hline Risk of bleeding & $\begin{array}{l}\text { Lack of correlation be- } \\
\text { tween residual factor } 8 \\
\text { level and bleeding risk. } \\
\text { Severe spontaneous bleed- } \\
\text { ing may occur in patients } \\
\text { with factor levels }>5 \%\end{array}$ & $\begin{array}{l}\text { Correlation between residual } \\
\text { factor } 8 \text { level and bleeding } \\
\text { risk. } \\
\text { Severe spontaneous bleeding } \\
\text { usually occur in severe he- } \\
\text { mophilia A patients with } \\
\text { factor levels }<1 \%\end{array}$ \\
\hline $\begin{array}{l}\text { Extensive hema- } \\
\text { toma/Subcuta- } \\
\text { neous bleeding }\end{array}$ & Common & Rare \\
\hline Hemarthrosis & Rare & Common \\
\hline Mortality & High & Not high \\
\hline
\end{tabular}

를 판단하면 안 되고, $37^{\circ} \mathrm{C}$ 에서 $1-2$ 시간 후에 결과를 판독해야 한다. 루 푸스항응고물질(lupus anticoagulant, LA)이 검출되는 항인지질항체증후 군(antiphospholipid antibody syndrome)에서도 연장된 aPTT 검사 결과 와 혼합검사에 연장된 $\mathrm{aPTT}$ 가 교정이 되지 않는 결과가 나오므로 후천성 혈우병 A를 진단하기 위해서는 LA 음성임을 확인해야 한다. 항인지질항 체증후군에서의 LA는 혼합검사에서 보통 상온에서 바로 교정이 안 되는 결과가 나오므로 후천성혈우병 $\mathrm{A}$ 와 혼합검사로 대략적으로 감별이 가능 하다. ${ }^{2,10}$

후천성혈우병 $\mathrm{A}$ 의 최종 진단은 감소된 혈중 8 번 응고인자 농도와 8 번 응고인자에 대한 자가항체의 확인으로 가능하다. 후천성혈우병 $\mathrm{A}$ 에서 관 찰되는 자가항체는 주로 면역글로불린G (immunoglobulin $\mathrm{G}, \mathrm{IgG}$ )이며, 응고인자 8번 경쇄의 C2 domain이나 A2 domain, A3 domain에 대한 직 접적인 항체이다. 혈우병에서 응고인자에 대한 항체의 농도는 주로 베데스 타 분석법(Bethesda assay)을 사용한다(Nijmegen 방법이 민감도를 올릴 수 있음). 항체의 양을 정량화할 때 1 Bethesda Unit (BU)은 8번 응고인자 활동도를 $50 \%$ 비활성화시키는 항체의 양으로 정의된다. 그러나, 후천성혈 우병 $\mathrm{A}$ 의 자가항체는 선천성혈우병 환자에서 발생하는 8 번 응고인자에 대한 항체에서 보이는 1형 역동학(kinetics)과는 달리 2형 역동학을 가지 고 있어서(non-linear complex inactivation pattern, 비선형 복합체 불활 성화 양상), 초기에 8 번 응고인자의 활동도를 빠르게 비활성화시키나 이후 에는 천천히 작용하기 때문에 베데스타 분석법으로 측정한 8 번 응고인자 에 대한 자가항체의 농도로 8 번 응고인자에 대한 비활성 강도를 정확히 예측하기 어렵다. ${ }^{10}$ 즉, 측정된 잔류 8 번 응고인자의 농도로 출혈의 정도를 예측하기 어렵다. 그러므로, 선천성혈우병과는 달리 $5 \%$ 이상의 8 번 응고 인자를 가지고 있는 후천성혈우병 $\mathrm{A}$ 에서도 치명적인 출혈이 발생할 수 있 다(Table 1).

\section{치료}

후천성혈우병 $\mathrm{A}$ 의 치료는 출혈과 관련된 합병증의 예방 및 치료와 응고인
자에 대한 항체 제거가 주요 목표가 되어야 한다. 또한 기저 동반질환이 확인된 경우에는 동반질환에 대한 치료도 같이 병행되어야 한다. 출혈의 위험이 있으므로 꼭 필요한 시술이 아니면 피해야 한다.

\section{출혈과 관련된 합병증의 치료}

후천성혈우병 $\mathrm{A}$ 에서 25-30\%에서는 출혈관련 합병증이 심하지 않아서 이 에 대한 지혈치료가 필요하지 않다. 측정된 잔류 8 번 응고인자 농도나 자 가항체의 농도로 출혈의 정도를 예측하기 어려우므로 임상적인 출혈 양 상에 따라 적절한 응고치료가 필요하다. ${ }^{1,2,8}$

후천성혈우병 A 환자에서는 8 번 응고인자에 대한 중화 자가항체가 있 으므로 8 번 응고인자의 응고기전을 우회하는 우회치료(bypassing therapy)가 필요하다. 우회치료로 활성화된 프로트롬빈 복합체 농축물(Activated prothrombin complex concentrate, aPCC [FVIII inhibitor bypassing activity, FEIBA, Baxalta, Bannockburn, IL, USA]) 50-100 units/kg 을 8-12시간마다 천천히 정주하거나(최대 용량 $200 \mathrm{U} / \mathrm{kg} / 24 \mathrm{hrs}$ ), 재조합 활성화 7번 응고인자(Recombinant activated factor VII, rFVIIa [NovoSeven, Novo Nordisk, Bagsvaerd, Denmark]) 70-90 $\mu \mathrm{g} / \mathrm{kg}$ 을 2-3시간마다 지혈이 될 때까지 투약한다. 지혈이 어느 정도 된 이후에는 투약 간격을 늘 릴 수 있다.1,2 유럽에서 진행된 대규모 European Acquired Haemophilia $(\mathrm{EACH} 2)$ registry 연구에서 출혈을 치료하기 위하여 사용된 약제는 $\mathrm{rF}$ VIIa (56.7\%), aPCC (20.5\%), 사람재조합 8번응고인자(18.2\%), 데스모프 레신(desmopressin, DDVAP, 4.6\%)으로, rFVIIa나 aPCC를 사용한 우회 치료로 $91.8 \%$ 에서 출혈을 조절할 수 있었다. 사람재조합 8 번 응고인자를 사용한 경우에는 낮은 출혈 조절률을 보였다 $(69.6 \%) .{ }^{11} \mathrm{rFVIIa}$ 나 aPCC를 사용한 우회치료를 시행할 경우 동맥이나 정맥의 혈전증의 위험이 증가할 수 있음을 고려해야 한다(EACH2 registry 연구에서 보고된 혈전증 빈도; rFVIIa $2.9 \%$, aPCC 4.8\%). ${ }^{11}$ 특히 고령에서 암을 동반하고 있거나 이전에 혈전증의 과거력이 있는 경우 주의해야 한다. aPCC 치료에 반응이 적절하 지 않은 경우에는 rFVIIa으로 치료약제를 변경하여 시도해 볼 수 있다. 후 천성혈우병 $\mathrm{A}$ 환자에서 주요 시술이나 수술이 필요한 경우에는 예방적으 로 이들 우회치료약제를 사용해야 한다. ${ }^{12}$ 이러한 우회치료약제를 사용할 수 없는 상황에서만 재조합 8 번 응고인자나 혈장유래 사람 응고인자 8 번 농축물을 사용하거나 ${ }^{13}$ 근거가 미약하지만 데스모프레신을 사용해 볼 수 있다. 주로 8 번 응고인자에 대한 자가항체 농도가 매우 낮은 경우에 주로 반응을 기대할 수 있다. 점막출혈이 있는 경우에는 신장 관련 출혈이 없다 면 우회치료약제에 추가로 항섬유소용해제(antifibrinolytic agents; tranexamic acid)를 추가로 사용해 볼 수 있다. ${ }^{2}$

우회치료약제에 대한 반응을 평가하는 표준화된 검사법이 없으므로 출혈에 대한 치료에 대한 반응 평가는 임상적으로 결정해야 한다. 8 번 응 고인자 농도가 회복이나 $\mathrm{aPTT}$ 가 정상화되는 것을 참고할 수는 있지만 근 거가 부족하므로, 임상적인 출혈 양상을 보고 우회치료약제 치료 반응을 평가하고 우회치료약제 치료 중단을 결정해야 한다.

\section{응고인자에 대한 항체 제거}

후천성혈우병 $\mathrm{A}$ 환자에게 출혈에 대한 합병증 치료에 추가로 발생한 8 번 응고인자에 대한 자가항체를 제거하기 위한 면역억제치료가 권고된다. 치 료를 하지 않아도 약 $30 \%$ 정도에서는 자연적으로 항체가 없어진다고 알 려져 있다. 특히 자가항체의 농도가 낮은 경우, 출산 후, 약제 관련 후천성 혈우병 $\mathrm{A}$ 환자에서 저절로 항체가 소실된다고 알려져 있다. 그러나, 이들 환자에서도 치명적인 출혈이 발생할 수 있으므로, 이에 대한 위험을 줄이 기 위해서는 모든 성인 후천성혈우병 $\mathrm{A}$ 환자에게 면역억제치료가 즉시 권 
고된다. 면역억제치료로 적절한 약제를 선택하기 위해서는 그동안 발표된 대규모 연구들을 검토해 보아야 한다. 영국에서 시도된 UKHCDO (United Kingdom Haemophilia Centre Doctors' Organisation) 감시 연구에서 는 $^{4}$ 스테로이드 단독치료(보통 매일 prednisolone $1 \mathrm{mg} / \mathrm{kg}$ )와 스테로이드 와 세포독성 약제(보통 매일 cyclophosphamide $1-2 \mathrm{mg} / \mathrm{kg}$ )의 병용치료 에 있어 완전관해 유도까지의 기간에 차이는 없었다(중앙값; 49일 vs. 39 일). 유럽에서 진행된 $\mathrm{EACH} 2$ registry ${ }^{14}$ 연구에서 1차 치료로 스테로이드 단독, 스테로이드+cyclophosphamide, 그리고, rituximab-기반 치료를 비 교하였다. 스테로이드+cyclophosphamide 치료군에서 더 높은 완전관해 율(80\%)과 더 짧은 관해 유도기간(40일)을 보고하였다(스테로이드 단독 군; $58 \%, 32$ 일, rituximab-기반 치료군; $61 \%, 64$ 일). 그러나, 생존율에서는 이들 3 군에 차이를 보이지 않았다. Acquired Hemophilia Working Group of the German, Austrian and Swiss Thrombosis and Hemostasis Society (GTH-AH) registry ${ }^{15}$ 의 전향적 연구 $(\mathrm{n}=102)$ 에서는 우선 1 차 치료제로 스테로이드 단독 $(60 \mathrm{~kg}$ 미만에서는 매일 prednisolone $75 \mathrm{mg} /$ 일, 60-100 $\mathrm{kg}$ 은 $100 \mathrm{mg}$ /일, $>100 \mathrm{~kg}$ 에서는 $150 \mathrm{mg}$ /일) 치료를 3주간 시도하고, 부 분관해에 도달하지 못하는 경우 스테로이드에 경구용 cyclophosphamide $(60 \mathrm{~kg}$ 미만에서는 $100 \mathrm{mg} /$ 일, $60-100 \mathrm{~kg}$ 은 $150 \mathrm{mg} /$ 일, $>100 \mathrm{~kg}$ 에서는 $200 \mathrm{mg}$ /일)를 추가하였고(4-6주째, $\mathrm{n}=35$ ), 이후에도 반응이 없으면 스테 로이드에 rituximab (375 mg/m²/주, 4주간)을 추가하였다(7-10주째, $\mathrm{n}=12$ ). 부분관해(정의; FVIII > $50 \mathrm{IU} / \mathrm{dL}$, 활동성 출혈 없음, 출혈억제를 위한 응 고치료약제 사용이 24 시간 이상 없음)는 $83 \%$ 에서 도달하였고(부분관해 도달일 중앙값; 31 일), 완전관해(정의; 부분관해+자가항체 음성, 감량된 prednisolone 용량 < $15 \mathrm{mg}$ /일, 다른 면역억제제 치료 중단)는 $61 \%$ 환자 에서 관찰되었다(완전관해 도달일 중앙값; 79 일). 1 년 생존율은 $68 \%$ 이었 다. 후천성혈우병 A 진단 시의 낮은 혈중 8 번응고인자 농도 $(<1 \mathrm{IU} / \mathrm{dL})$ 를 가진 경우 치료에 따른 완전관해율이 낮았다. 베데스타 분석법으로 측정 한 항체에 대한 BU값보다는 효소면역측정법(Enzyme-Linked ImmunoSorbent Assay, ELISA)으로 측정한 8번 응고인자에 대한 면역글로불린G 가 높은 경우 치료에 대한 반응이 불량하였다. ${ }^{16}$ 또한, 진단 시의 8 번 응고 인자에 대한 면역글로불린A가 높은 경우와 불량한 전신상태(WHO 전신 상태 <2)를 보인 환자군에서 불량한 치료반응과 짧은 생존율을 보였다. ${ }^{17}$ 진단 시 악성종양을 동반한 경우에도 다른 동반질환을 가진 경우보다 짧 은 생존율을 보였다..$^{5,17}$

결론적으로 후천성혈우병 $\mathrm{A}$ 환자의 1 차 면역억제치료로는 스테로이드 단독치료가 가능하며, 비록 장기 생존율의 이득은 확인되지 않았지만 스 테로이드+경구용 cyclophosphamide 치료도 1차 치료로 시도해 볼 수 있 을 것으로 판단된다. 이들 치료에 반응이 적절하지 않은 경우에는 ritux- imab-기반 치료를 시도해 볼 수 있다. Rituximab 이외에도 mycophenolate mofetil, azathioprine, vincristine 그리고 cyclosporine 등을 이용한 면역억제 치료도 고려해 볼 수 있다. 고용량의 면역글로불린 주사(intravenous immunoglobulin)는 권고되지 않는다. 면역억제치료 중 감염의 위험 이 증가하고, 이와 관련된 사망도 보고되고 있어서 면역억제치료 중 보존 적 치료에 대한 철저한 감시가 요구된다. ${ }^{1,2,12}$

임신과 관련하여 발생한 후천성혈우병 $\mathrm{A}$ 환자는 자연적으로 회복되는 경우도 있고 다른 원인에 의한 후천성혈우병 $\mathrm{A}$ 보다는 전체 생존율이 좋 다. 면역억제치료는 산모나 태아에 대한 독성을 고려하여 스테로이드 단 독을 1차 치료로 권고하고 있다. Cyclophosphamide는 임신이나 수유 중 에 안전하지 않다고 알려져 있다. ${ }^{2,18}$

후천성혈우병 $\mathrm{A}$ 환자에서 면역억제치료 중에는 치료 반응과 재발 여부 판단을 위해서 매주 8 번응고인자 농도와 항체농도를 측정할 것을 권고하 고 있고, ${ }^{2}$ 자가항체가 음전이 되는 완전관해에 도달한 이후에도 $15-24 \%$ 의 재발이 보고되고 있어, 6 개월간 매달, 이후 1년까지 2-3개월마다 추적 검 사를 권고하고 있다. 완전관해 도달 1 년 이후에도 6 개월마다 재발에 대한 추적 검사가 필요하다. ${ }^{12}$

\section{결론}

후천성혈우병 $\mathrm{A}$ 는 자가면역질환의 하나로 선천성혈우병과 다른 임상양 상과 기전을 가지고 있으므로 질환에 대한 정확한 이해와 적절한 진단이 중요하다. 출혈 질환에 대한 과거력이 없는 환자에서 설명할 수 없는 $\mathrm{aPTT}$ 값의 연장을 보이면서 출혈 경향을 보이는 경우 반드시 후천성혈우병 $\mathrm{A}$ 를 고려해야 한다. 또한 측정된 잔류 8 번 응고인자의 농도로 출혈의 정도를 예측하기 어려우므로 임상적인 출혈 양상에 따라 적극적인 초기 치료가 필요하다. 출혈과 관련된 합병증의 예방 및 치료를 위한 우회치료와 면역 억제제를 사용한 응고인자에 대한 항체 제거가 치료의 주요 목표가 되어 야 한다. 비교적 드문 질환으로 여전히 표준치료 지침에 대한 자료가 많이 부족한 상황으로 대부분 후향적 연구 결과에 따른 전문가의 권고에 의존 하고 있다. 효과적인 치료방법 확립을 위해서는 다기관 연구가 활발히 진 행되어야 할 것으로 판단된다.

\section{Acknowledgement}

이 논문은 한국혈전지혈학회의 연구비를 지원받아 진행되었음(KSTH 2016-003).

\section{References}

1. Webert KE. Acquired hemophilia A. Semin Thromb Hemost 2012;38:735-41.

2. Kruse-Jarres R, Kempton CL, Baudo F, Collins PW, Knoebl P, Leissinger CA, et al. Acquired hemophilia A: Updated review of evidence and treatment guidance. Am J Hematol 2017;92:695-705.

3. Knoebl P, Marco P, Baudo F, Collins P, Huth-Kuhne A, Nemes L, et al. Demographic and clinical data in acquired hemophilia A: results from the European Acquired Haemophilia Registry (EACH2). J Thromb Haemost 2012;10:622-31.

4. Collins PW, Hirsch S, Baglin TP, Dolan G, Hanley J, Makris M, et al. Acquired hemophilia A in the United Kingdom: a 2-year national surveillance study by the
United Kingdom Haemophilia Centre Doctors' Organisation. Blood 2007;109:1870-7.

5. Lee JH, Kim DH, Yoo K, Choi Y, Kim SH, Kim HJ. The first case of postpartum acquired hemophilia A in Korea. J Korean Med Sci 2011;26:1247-9.

6. Lee KS, Shim YJ, Jang KM, Hyun SY. Second case of postpartum acquired hemophilia $\mathrm{A}$ in a Korean female. Blood Res 2014;49:205-7.

7. Kim MS, Kilgore PE, Kang JS, Kim SY, Lee DY, Kim JS, et al. Transient acquired hemophilia associated with Mycoplasma pneumoniae pneumonia. J Korean Med Sci 2008;23:138-41.

8. Sborov DW, Rodgers GM. How I manage patients with acquired haemophilia A. Br J Haematol 2013;161:15765.

9. Collins P, Baudo F, Huth-Kuhne A, Ingerslev J, Kessler $\mathrm{CM}$, Castellano ME, et al. Consensus recommenda- tions for the diagnosis and treatment of acquired hemophilia A. BMC Res Notes 2010;3:161.

10. Tiede A, Werwitzke S, Scharf RE. Laboratory diagnosis of acquired hemophilia A: limitations, consequences, and challenges. Semin Thromb Hemost 2014;40: 803-11.

11. Baudo F, Collins P, Huth-Kuhne A, Levesque H, Marco P, Nemes L, et al. Management of bleeding in acquired hemophilia A: results from the European Acquired Haemophilia (EACH2) Registry. Blood 2012; 120:39-46.

12. Huth-Kuhne A, Baudo F, Collins P, Ingerslev J, Kessler $\mathrm{CM}$, Levesque $\mathrm{H}$, et al. International recommendations on the diagnosis and treatment of patients with acquired hemophilia A. Haematologica 2009;94:566-75.

13. Kruse-Jarres R, St-Louis J, Greist A, Shapiro A, Smith $\mathrm{H}$, Chowdary $\mathrm{P}$, et al. Efficacy and safety of OBI-1, an 
antihaemophilic factor VIII (recombinant), porcine sequence, in subjects with acquired haemophilia A. Haemophilia 2015;21:162-70.

14. Collins P, Baudo F, Knoebl P, Levesque H, Nemes L, Pellegrini F, et al. Immunosuppression for acquired hemophilia A: results from the European Acquired Haemophilia Registry (EACH2). Blood 2012;120:47-55.

15. Tiede A, Klamroth R, Scharf RE, Trappe RU, Holstein K, Huth-Kuhne A, et al. Prognostic factors for remis- sion of and survival in acquired hemophilia A (AHA): results from the GTH-AH 01/2010 study. Blood 2015; 125:1091-7.

16. Werwitzke S, Geisen U, Nowak-Gottl U, Eichler H, Stephan B, Scholz U, et al. Diagnostic and prognostic value of factor VIII binding antibodies in acquired hemophilia A: data from the GTH-AH 01/2010 study. J Thromb Haemost 2016;14:940-7.

17. Tiede A, Hofbauer CJ, Werwitzke S, Knobl P, Gottstein
S, Scharf RE, et al. Anti-factor VIII IgA as a potential marker of poor prognosis in acquired hemophilia A results from the GTH-AH 01/2010 study. Blood 2016; 127:2289-97.

18. Tengborn L, Baudo F, Huth-Kuhne A, Knoebl P, Levesque $\mathrm{H}$, Marco $\mathrm{P}$, et al. Pregnancy-associated acquired haemophilia A: results from the European Acquired Haemophilia (EACH2) registry. BJOG 2012;119:152937. 